\title{
Görünmeyen Sınırların Kentsel Dönüşüm Projeleri ile Değişimi: İzmir Kadifekale Örneği
}

\author{
Merve AKDAŞ ${ }^{1 *}$
}

Öz

Kent, makro ve mikro ölçekte, görünen ve görünmeyen pek çok sınır içerir. Sosyoekonomik nedenlere bağlı olarak ortaya çıkan bu sınırlar, kimi zaman duvar, tabela gibi somut elemanlarla kimi zaman ise soyut çizgiler ve kurallarla mekânsal ayrışmaları tanımlı kılar. Bu çalışmanın amacı, kentsel dönüşüm projesi öncesi ve sonrasındaki durumu "görünmeyen sınırlar" üzerinden tartışmaktır. Çalışma kapsamında İzmir'in Konak ilçesinde yer alan Kadifekale Mahallesi incelenmiştir. Başta prestijli bir kent merkezi olan Kadifekale, 1950'lerden sonra aldığı yoğun göç ve çarpık kentleşme sonucu İzmir'in ilk ve en geniş gecekondu bölgelerinden biri olmuştur. 2007 yılında Kadifekale Kentsel Dönüşüm Projesi kapsamında bölgedeki konutların bir kısmı boşaltılmış ve ailelerin birçoğu İzmir'in Karabağlar ilçesinde yer alan Uzundere Toplu Konut Alanına taşınmıştır. Konuyla ilgili yapılan araştırmalar ve alanda gerçekleştirilen enformel görüşmeler doğrultusunda, kentsel dönüşüm projesi öncesi ve sonrasındaki durum, makro ölçekte "kentli" ile Kadifekaleli arasındaki görünmeyen sınırlar üzerinden incelenirken mikro ölçekte ise, Kadifekalelilerin kendi içinde inşa ettiği görünmeyen sınırlar ele alınmıştır. Kentsel dönüşüm projesiyle, Kadifekalelilerin hayatında var olan sınırların yok olmayıp sadece yer değiştirdiği ve mevcut sınırlara yenilerinin eklenmesiyle ayrışmanın derinleştiği görülmüştür.

Anahtar Kelimeler: Sınır, Mekansal ayrışma, Kentsel dönüşüm projesi, Kadifekale

\section{Change of the Invisible Boundaries with Urban Renewal Projects: The Case of Izmir Kadifekale}

\begin{abstract}
\footnotetext{
${ }^{1}$ Gazi Üniversitesi, Fen Bilimleri Enstitüsü, Mimarlık Anabilim Dalı

* İlgili yazar/Corresponding author: merve.akdash@gmail.com

Gönderim Tarihi / Received Date: 04.12.2020

Kabul Tarihi / Accepted Date: 03.08.2021
}

The city contains many visible and invisible boundaries, in macro and micro scales. These boundaries, which emerged due to socio-economic reasons, define spatial segregations by sometimes being a concrete element such as wall and signboard or sometimes creating abstract lines and rules. Aim of this study is to discuss the situation before and after the renewal project over "invisible boundaries". Kadifekale Neighborhood in Konak, district of Izmir, is analyzed within the scope of the study. Due to the intense immigration and unplanned urbanization during 1950s, Kadifekale, once a prestigious city center, became one of the first and largest slum areas in İzmir. In 2007, a part of the dwellings was demolished during the Kadifekale Urban Renewal Project and families moved to Uzundere Mass Housing Area in Karabağlar. According to the researches upon the subject and informal interviews in the field, the situation before and after the urban renewal project is examined through invisible boundaries between the "urbanite" and Kadifekale residents in a macro scale while a micro scaled analysis is conducted to understand the invisible boundaries among Kadifekale residents. With the 
urban renewal project, the existing boundaries, in the lives of Kadifekale residents, did not disappear but only displaced and segregation deepened with the addition of new boundaries.

Keywords: Boundary, Spatial Segregation, Urban Renewal Project, Kadifekale

\section{Giriş}

Ekonomik gelişme ve büyümenin temel kaynaklarından biri olarak görülmeye başlanan kentsel politikalar, giderek artan bir biçimde girişimci bir anlayışıyla belirlenir hale gelmiştir. Kentlerin pazarlanması ve kent merkezlerinin turizm için bir çekim alanı şeklinde yeniden düzenlenmesi adına, alt gelir grupları kent merkezinden uzaklaştırımaktadır. Resmî söylemde; "yaşam koşullarının iyileştirilmesi", "kültür endüstrisi ve turizm açısından başat kentler arasına girmek" gibi ifadelerle kendini meşrulaştıran bu neo-liberal kent politikaları, günümüzde kentsel dönüşüm projesi adı altında adeta bir soylulaştırma süreci şeklinde devam etmektedir (Sönmez 2014:43).

Kentsel Dönüşüm Projeleri esasında, kentleşme ile artan kentsel sorunlara çözüm arayışlarına yönelik bir çözüm olarak gündeme gelmiştir. Akkar (2006), kentsel dönüşümü "çökme ve bozulma olan kentsel mekanın ekonomik, toplumsal, fiziksel ve çevresel koşullarını kapsamlı ve bütünleşik yaklaşımlarla iyileştirmeye yönelik uygulanan strateji ve eylemlerin bütünüdür" ifadesiyle tanımlamaktadır (Akkar 2006: 29). Roberts'a (2000) göre ise kentsel dönüşüm, yitirilen bir ekonomik etkinliğin yeniden geliştirilmesi ve canlandırılması, işlemeyen bir toplumsal işlevin işler hale getirilmesi; toplumsal dışlanma olan alanlarda, toplumsal bütünleşmenin sağlanması; çevresel kalitenin veya ekolojik dengenin kaybolduğu alanlarda, bu dengenin tekrar sağlanmasıdır. Ancak Ülkemizde kentsel dönüşüm projelerinin uygulandığı alanlar çoğunlukla gecekondu bölgeleridir. Kentsel dönüşüm kavramı Türkiye pratiğine özellikle 1999 Marmara depremi ile girmiştir ancak Türkiye'deki kentsel dönüşüm sürecinin temel sorunu gecekondu alanlarıdır (Görgülü 2009: 771). Bu kentsel dönüşüm projeleri, kentsel dönüşümün tanımında belirtildiği şekilde toplumsal bütünleşmeyi sağlamanın aksine, görünen ve görünmeyen birtakım sınırları besleyerek, toplumsal ayrışmayı daha da görünür kılmaktadır.

Eşit yaşam koşullarına sahip olmayan kent bölgelerini tanımlı kılan sınırlar; fiziksel, kültürel ve sosyal kurgularla şekillenen, insanları ayıran veya onları bir arada tutmak için çevreleyen, insanların ilişkilerini düzenleyen öğelerdir. TDK 'ya göre sınır kavramının sözlükteki ilk anlamı; "iki komşu devletin topraklarını veya il, ilçe, köy ya da kişilerin topraklarını birbirinden ayıran çizgi"dir. İkinci anlamı ise; "bir şeyin yayılabileceği ya da genişleyebileceği son çizgi, uç" şeklindedir. İnsanoğlunun doğadan görerek öğrendiği ve zaman içinde zenginleştirdiği sınır kavramının temelinde, insanın kendi egemenlik alanını belirlemesi, kendi merkezini sınırlaması ve dışa karşı koruması düşüncesi yatmaktadır (Mumcu Uçar ve Özsoy, 2006: 12). "İç ve dış" arasındaki farklılaşmanın başladığı yer olan "sınır" Marcuse (1999: 110) 'a göre kişiler ve aktiviteler arasındaki "bölümlenmeleri" sağlar. Başka bir deyişle sosyal anlamda bölümlenme, kültürel, politik veya ekonomik nedenlerle görünen ve görünmeyen sınırların varlığını gerektirir. Lang (1987), "Creating architectural theory: The role of behavioral sciences in environmental design" adlı kitabında her ölçekteki kültürel bilgiyi barındıran yapay çevrenin, onu oluşturan sosyal organizasyonları yansıttığını dile getirmiştir. Dolayısıyla her ölçekteki mekânda bu ayrımların yansımaları görülebilmektedir. 
Kenti şekillendiren önemli öğelerden biri olan "sınır" farklılıklar arasındaki ilişkiyi kimi zaman duvar, tabela gibi somut elemanlarla yani görünen sınırlarla şekillendirirken kimi zaman da soyut şekillerle, kurallarla yani görünmeyen sınırlarla belirler. Sınırlar, daha çok ayırma işleviyle bilinse de tarafların karşılaştığı ve etkileştiği dinamik ara kesitlerdir (Cruz ve Boddington, 1999). Günümüzde karmaşıklaşan sosyal ilişki ağlarıyla daha da artmakta olan sınırlar, özellikle görünmeyen ve rijit olmayan soyut sınırlarla varığını sürdürmektedir. Modernizm öncesi daha tanımlı olan kent sınırları/dış sınırları günümüzde daha belirsiz hale gelirken, bunun yerine kentin içindeki sınırlar derinleşmiştir (Mumcu Uçar ve Özsoy, 2006: 15).

Farklılıkları belirginleştirerek keskinleştiren sınırlar, iç ve dış arasındaki ilişkiyi kopararak toplumsal ayrımlaşmaları beslemektedir. Kent bütünlüğünü yok eden bu sınırlar "öteki"lerin dahil olmasına izin vermeyen özel alanlar oluşturmakta ve bu nedenle bireyler farklılıklarını paylaşarak olgunlaşma olanağını kaybetmektedir. Sınırların neden olduğu bu toplumsal ayrışma en çok konutlarda kendini göstermektedir. Bu nedenle "görünmeyen sınır"ları yerleşim alanı olan Kadifekale Mahallesi üzerinden tartışmanın yararlı olacağı düşünülmüştür. Konuyla ilgili yapılan araştırmalar ve alanda gerçekleştirilen enformel görüşmeler doğrultusunda, kentsel dönüşüm projesi öncesi ve sonrasındaki durum, makro ölçekte "kentli" ile Kadifekaleli arasındaki görünmeyen sınırlar üzerinden ele alınacak daha sonra ise mikro ölçekte, Kadifekalelilerin kendi içinde inşa ettiği görünmeyen sınırlardan bahsedilecektir. Kadifekale sakinlerinin, "kentli" kimliği taşıyan kişilerle ve Kadifekalelilerin kendi aralarında inşa ettikleri görünmeyen sınırları anlamak adına Kadifekale'nin geçirdiği tarihsel süreçten de kısaca bahsetmek gerekir.

\section{Tarihsel Süreç İçinde Kadifekale}

İzmir'in Konak ilçesinde bulunan Kadifekale Mahallesinin yer aldığı bölge, antik kaynaklarda Pagos Tepesi adıyla anılmaktadır. Tarihi öneme sahip olan bölgede ilk yerleşim faaliyetleri M.Ö. 4. yüzyılda görülmüştür. Bayraklı da yer alan eski İzmir kenti M.Ö. 545 yılında Pers saldııları sonucu yıkımlara maruz kalmış, bu nedenle yeni Smyrna kenti daha güvenli olan Pagos tepesine kurulmuştur (Karayiğit, 2005: 4). Dönemin önemli liman kentlerinden biri olan Smyrna kenti Helenistik Dönem tarzına uygun planlanmış görkemli bir akropoldür. Su kemerleri, stadyumu, tiyatrosu ve agorasıyla oldukça gelişmiştir. Pagos Tepesi, kenti, kente uzanan yolları ve körfezi gözetleme imkânı sunduğu için bulunduğu çağın gereksinimlerini karşılamaktadır (Göncü, 2013: 1). Tarih boyunca, stratejik konumu nedeniyle önemli bir üs olan bölge, aynı zamanda Cumhuriyet öncesinde Müslüman Türk mahallelerinin bulunduğu tarihi bir alandır (Şekil 1). İzmir kent kimliğinin önemli öğelerinden biri olan ve toplumsal hafızada da simgesel bir değere sahip olan Kadifekale'nin geçirdiği önemli dönüm noktaları Tablo 1 de özetlenmiştir. 


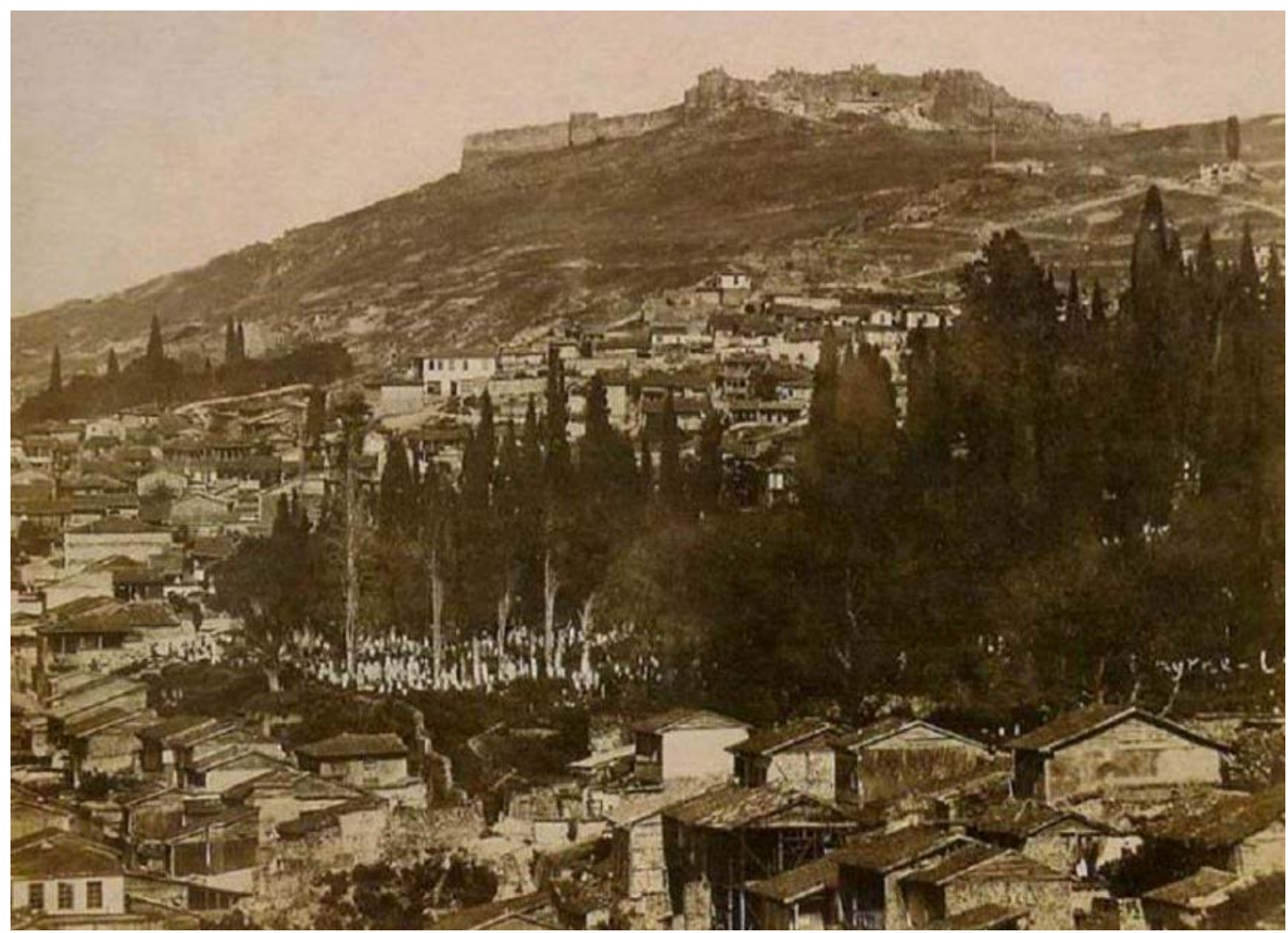

Şekil 1. 1870'lerde Kadifekale (URL-1)

Tablo 1. Kadifekale tarihinin önemli dönüm noktaları

\begin{tabular}{|l|l|}
\hline 11.Yüzyilin Sonu & Çaka Bey İzmir'i Bizanslılardan aldı, böylece bölge ilk kez Türk hakimiyetine geçti. \\
\hline 14.Yüzyilin Başları & $\begin{array}{l}\text { Çaka Bey'in İzmir'i almasından bir süre sonra İzmir tekrar Bizans hakimiyetine girdi. Bölge } \\
\text { Türk yönetimine daimi olarak Aydınoğlu Umur Bey'in kaleyi ele geçirmesiyle geçti. }\end{array}$ \\
\hline 16. Yüzyilin Sonu & $\begin{array}{l}\text { Bu döneme kadar onarımlarla kale hala önemini korudu ancak bu tarihten sonra bölge } \\
\text { 1ssızlaşmaya başladı. }\end{array}$ \\
\hline 18. Yüzyil & $\begin{array}{l}\text { Bölge bu tarihe kadar yerleşim alanı olarak kullanılmadı ancak bu tarihten sonra kalenin } \\
\text { taşları sökülerek bu taşlarla kale civarında yapılar inşa edildi. Stadyum, tiyatro gibi tarihi } \\
\text { yapıllar bu yağmalar sonucu yok oldu. }\end{array}$ \\
\hline 18. Yüzyil Sonrasi & $\begin{array}{l}\text { Bölge tekrar yerleşime açıldı ve Osmanlı tarzı bir yaplaşma kendini gösterdi ancak bu } \\
\text { yapılların çok az bir kısmı belli belirsiz olarak günümüze kadar gelebildi. }\end{array}$ \\
\hline 1950'lerden Sonra & $\begin{array}{l}\text { Bölgede gecekondulaşma başladı. 1978'de Bakanlar Kurulu tarafindan heyelan tehlikesi } \\
\text { nedeniyle kale çevresi afet bölgesi ilan edildi ancak bu karar bile kaçak yapıllaşmanın önüne } \\
\text { geçemedi }\end{array}$ \\
\hline 1980-2000 & $\begin{array}{l}\text { Bölge, bu dönemde Doğu ve Güneydoğu Anadolu bölgesinde yaşanan terör olayları } \\
\text { sebebiyle bu bölgelerden yoğun göç aldı (Karayiğit,2005). }\end{array}$ \\
\hline
\end{tabular}

Kadifekale Mahallesi bir zamanlar mesire yerleri, eğlence mekânları ve gazinoları ile anılan, kentin prestijli alanlarından biriydi (Şekil 2). Özel konumuna ve tarihi yapısına rağmen 1950'lerden sonra aldığı yoğun göçle çarpık kentleşme sürecine girerek İzmir'in ilk ve en geniş gecekondu bölgelerinden biri olmuştur. Gelir seviyesi düşük insanların yaşadığı bölge oldukça yüksek suç oranları ile bilinmektedir. Nüfus artış hızı Türkiye ortalamasının oldukça üstünde olan bölgede nüfusun büyük çoğunluğunu Doğu ve Güneydoğulu vatandaşlar, özellikle de Mardinliler oluşturmaktadır. Yoğun nüfus 
barındıran semtte yoğun yapılaşma vardır ve mahalle sakinleri elverişsiz yaşam koşullarında hayatlarını devam ettirmektedir.
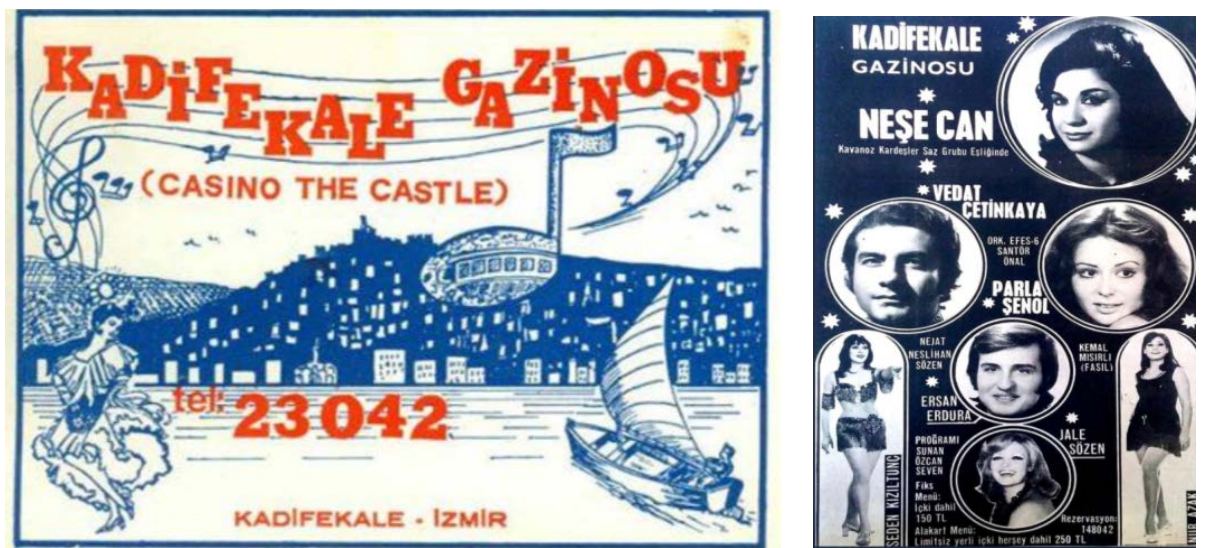

Şekil 2. 1970'li yıllarda Kadifekale'deki eğlence yerlerine ilişkin ilan ve fotoğraflar (URL-2,URL-3)

İzmir'de kentsel dönüşüm için öncelikli proje uygulama alanlarından biri olarak Kadifekale belirlenmiştir. Bölgede bulunan heyelan riski dolayısıyla Bakanlar Kurulu tarafından Kadifekale'ye ilişkin 1978, 1981, 1998 ve 2003 tarihlerinde çıkarılan Afete Maruz Bölge kararları (Tekeli, 2018:47) bu dönüşümün meşru söylemini oluşturmaktadır. Projenin diğer nedenleri arasında ise coğrafi konumu nedeniyle kent prestiji bakımından önem taşıması ve tarihi önemi nedeniyle kent turizminin geliştirilmesine yönelik sahip olduğu potansiyeldir (Fot. 1, Fot. 2) (Mirioğlu,2013,81). 2006 tarihinde alana ilişkin kamulaştırma kararı alınmıştır (Savcı 2009: 251, Akdağ 2009: 760). 2007 tarihinde onaylanan İzmir Kentsel Bölge Nazım İmar planında Kadifekale Kentsel Dönüşüm Proje alanı rekreasyon alanı, çevresi de kentsel yenileme alanı olarak planlanmıştır (Mutlu 2009, 73). Kadifekale ve çevresinin arkeolojik sit alanı olarak korunması ve düzenlenmesine yönelik Kültür Bakanlığı tarafından birçok çalışma yürütülmüştür (Fot. 3, Fot. 4).

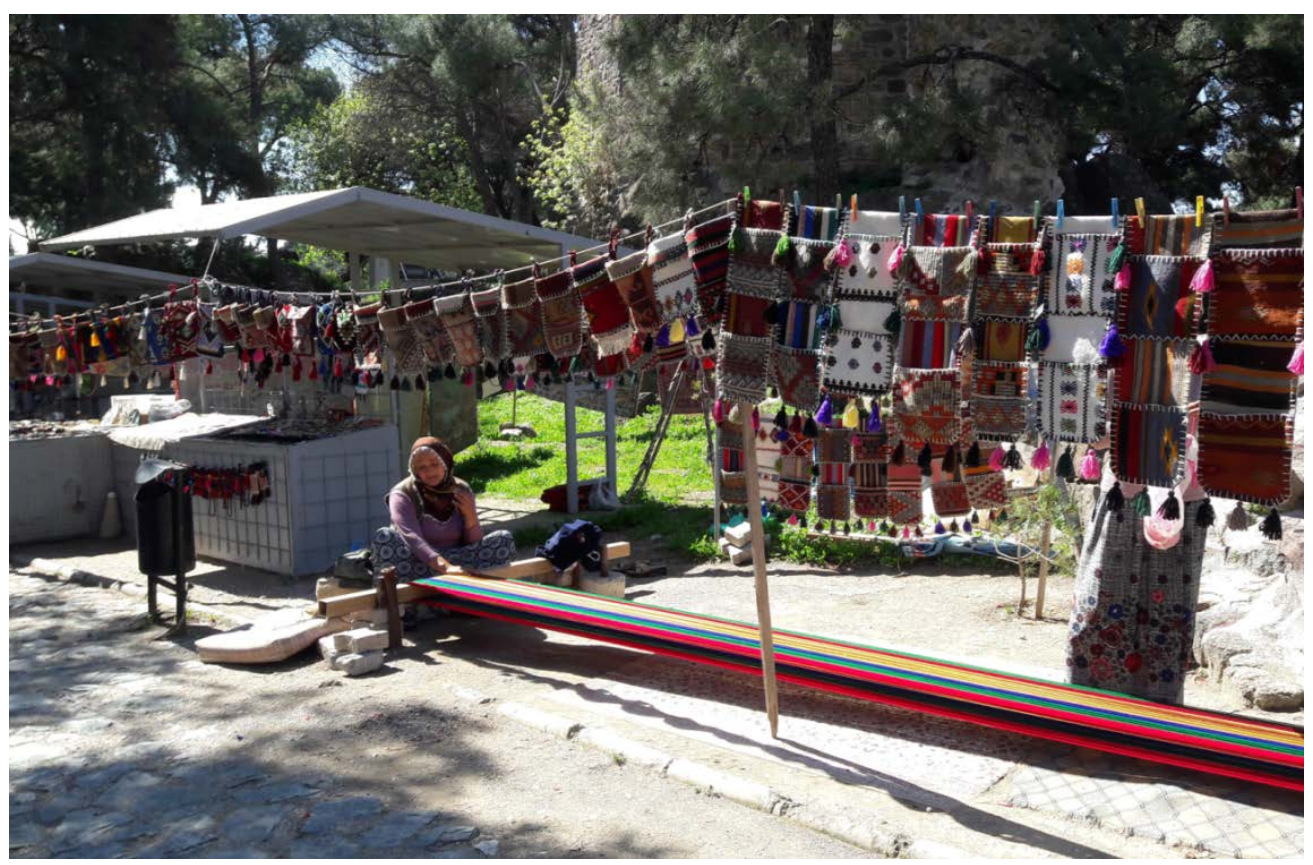

Fotoğraf 1. Turizme yönelik çalışmalar; kadınlar tarafından dokuma çanta yapılıp satılmaktadır 
Görünmeyen Sınırların Kentsel Dönüşüm Projeleri ile Değişimi: İzmir Kadifekale Örneği

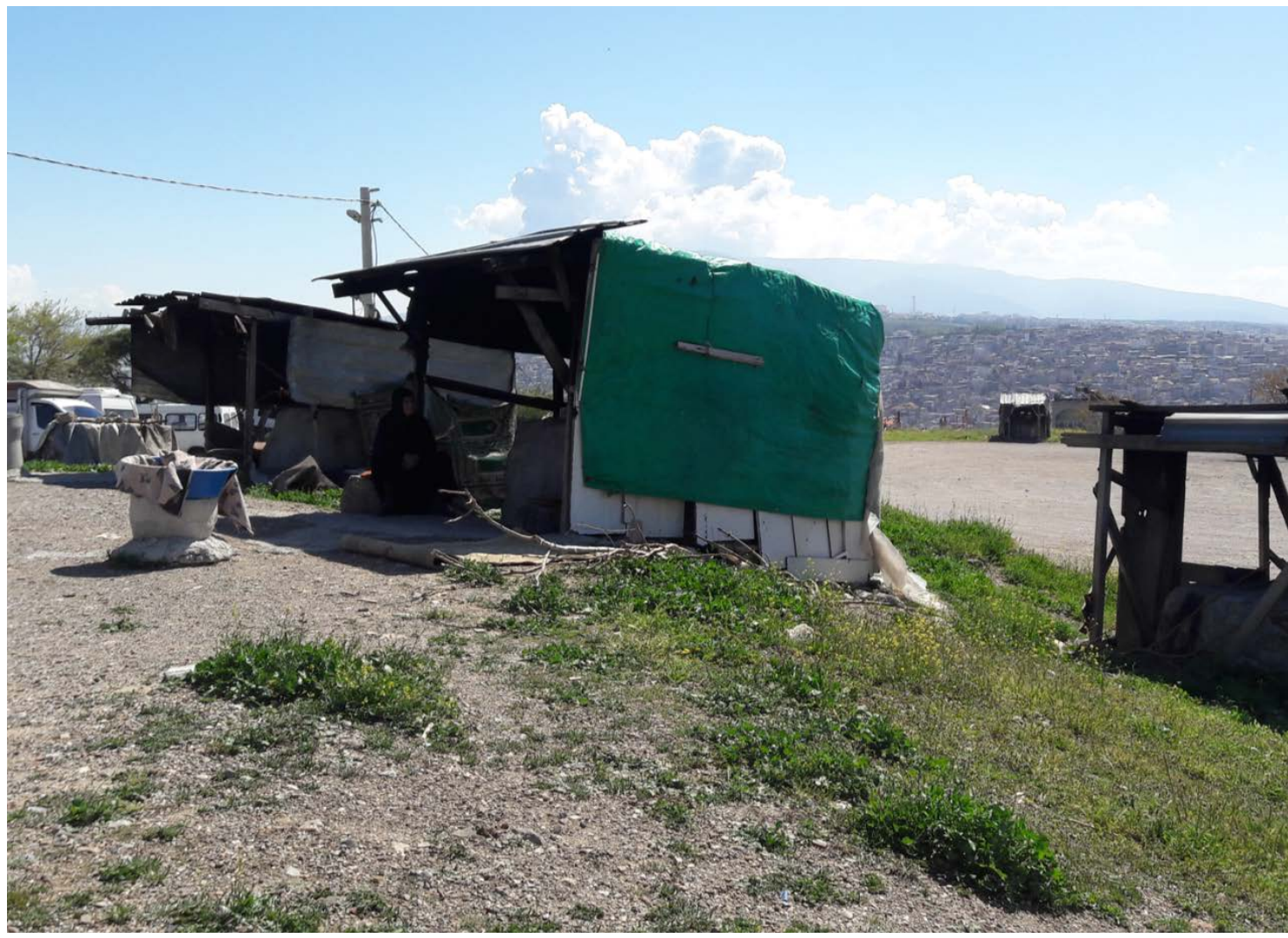

Fotoğraf 2. Turizme yönelik çalışmalar; kadınlar tandır ekmeği yapıp satmaktadır

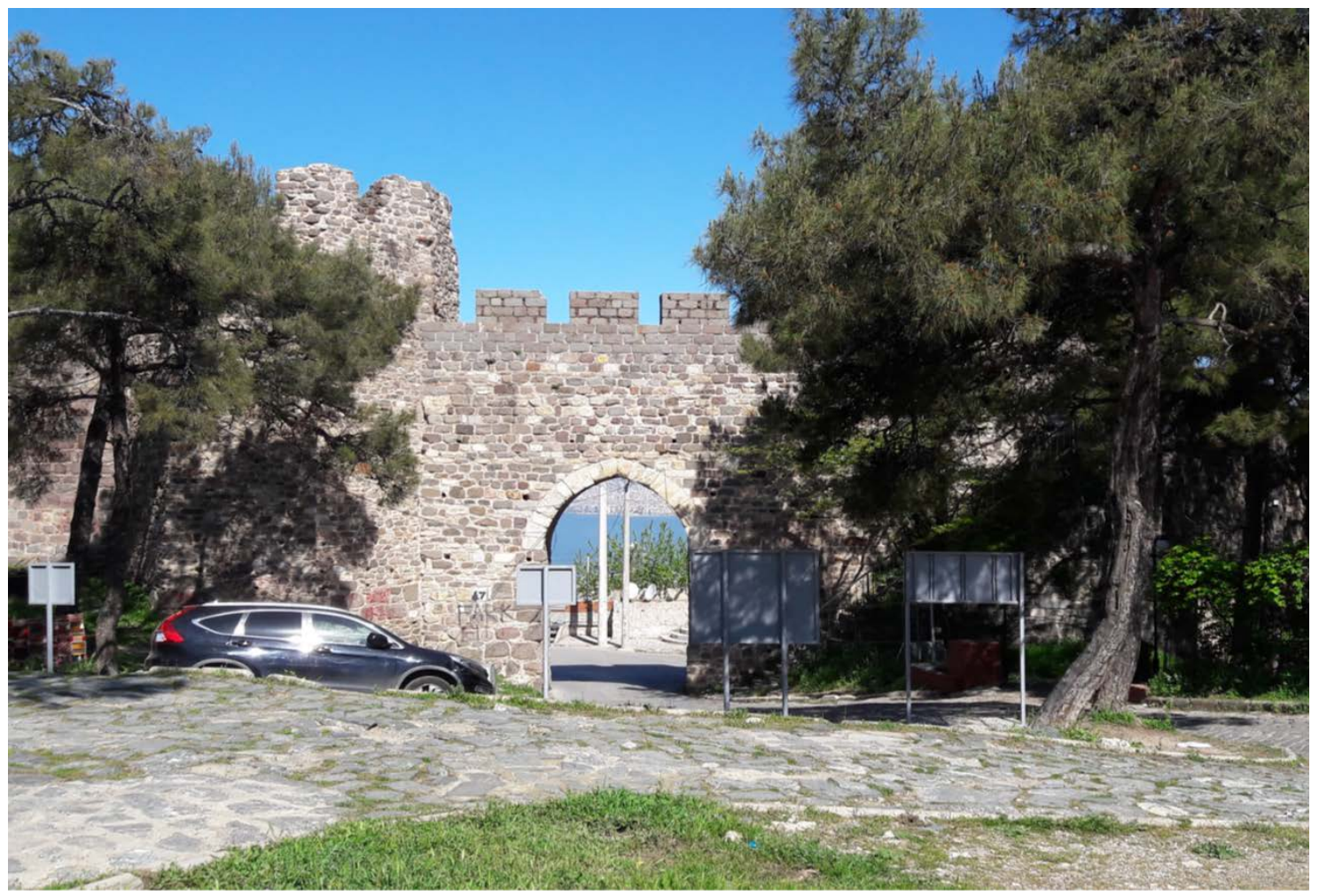

Fotoğraf 3. Restorasyon sonrası Kadifekale 


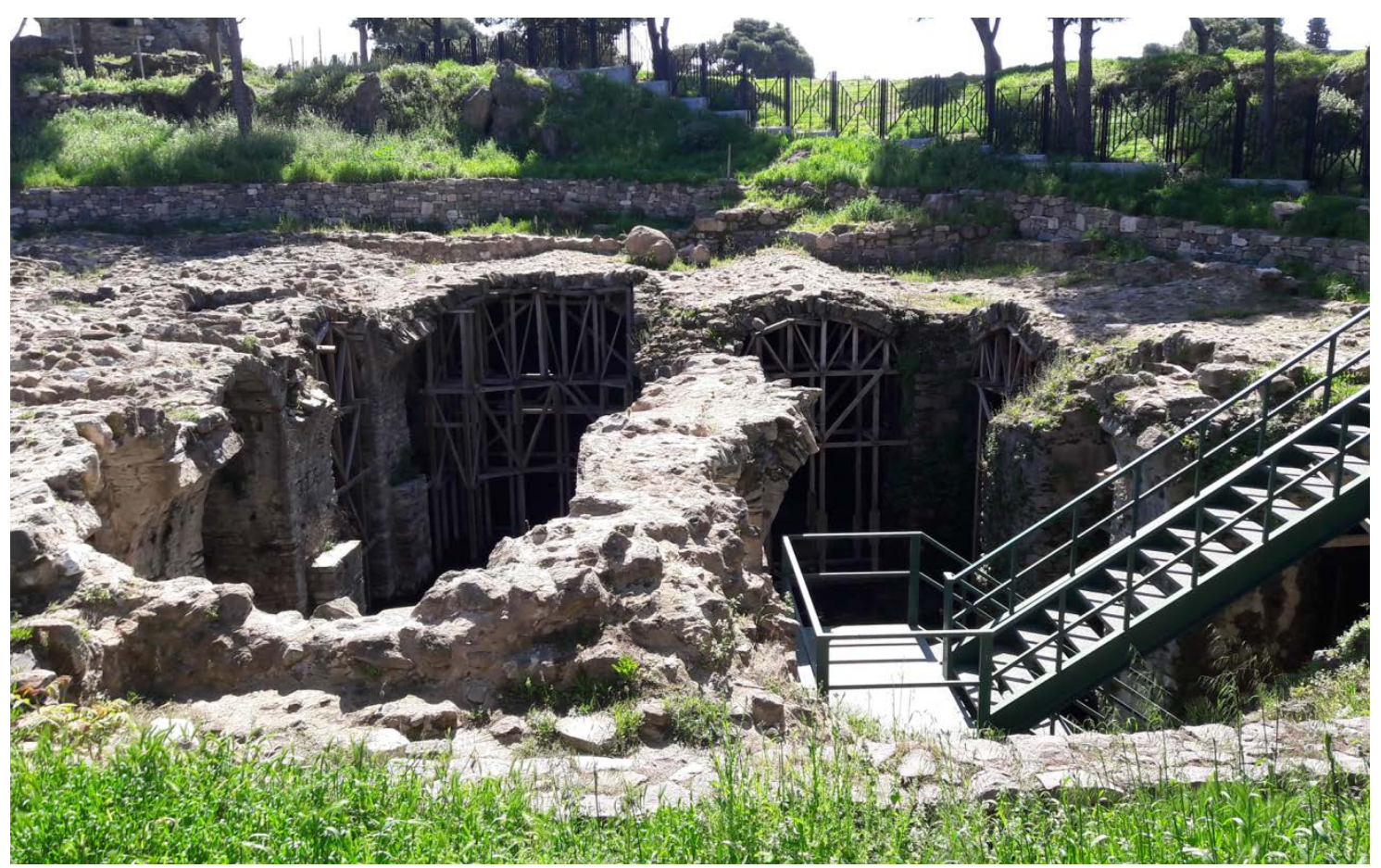

Fotoğraf 4. Restorasyon sonrası Kadifekale

Proje İzmir Büyükşehir Belediyesi Konak ilçe sınırları içerisinde, 42 hektarlık bir alanı kaplamaktadır. Bu alanda 1968 adet yapı ve 20.000 kişi bulunmaktadır (İzmir Büyükşehir Belediyesi Kentsel Dönüşüm Şube Müdürlüğü, Mart 2013). Dolayısıyla çok sayıda insanın hayatını etkileyecek bir projedir. İlk yıkımlar 2007 tarihinde başlamış ve konut teslimleri ile hız kazanan yıkım işlemleri sonucunda bölgedeki 1968 adet yapının 1967 adedi yıkılmıştır (Fot. 5). Kadifekale Kentsel Dönüşüm Projesi kapsamında boşaltılan konutlarda yaşayan aileler Karabağlar ilçesindeki Uzundere Toplu Konutlarına taşınmıştır (Fot. 6). Uzundere'ye gitmek istemeyen hak sahipleri ise kamulaştırma bedellerini nakit olarak almışlardır (Mirioğlu, 2013: 80). Uzundere, Kadifekale ile kıyaslandığında kent merkezine oldukça uzak bir konumda yer almaktadır.

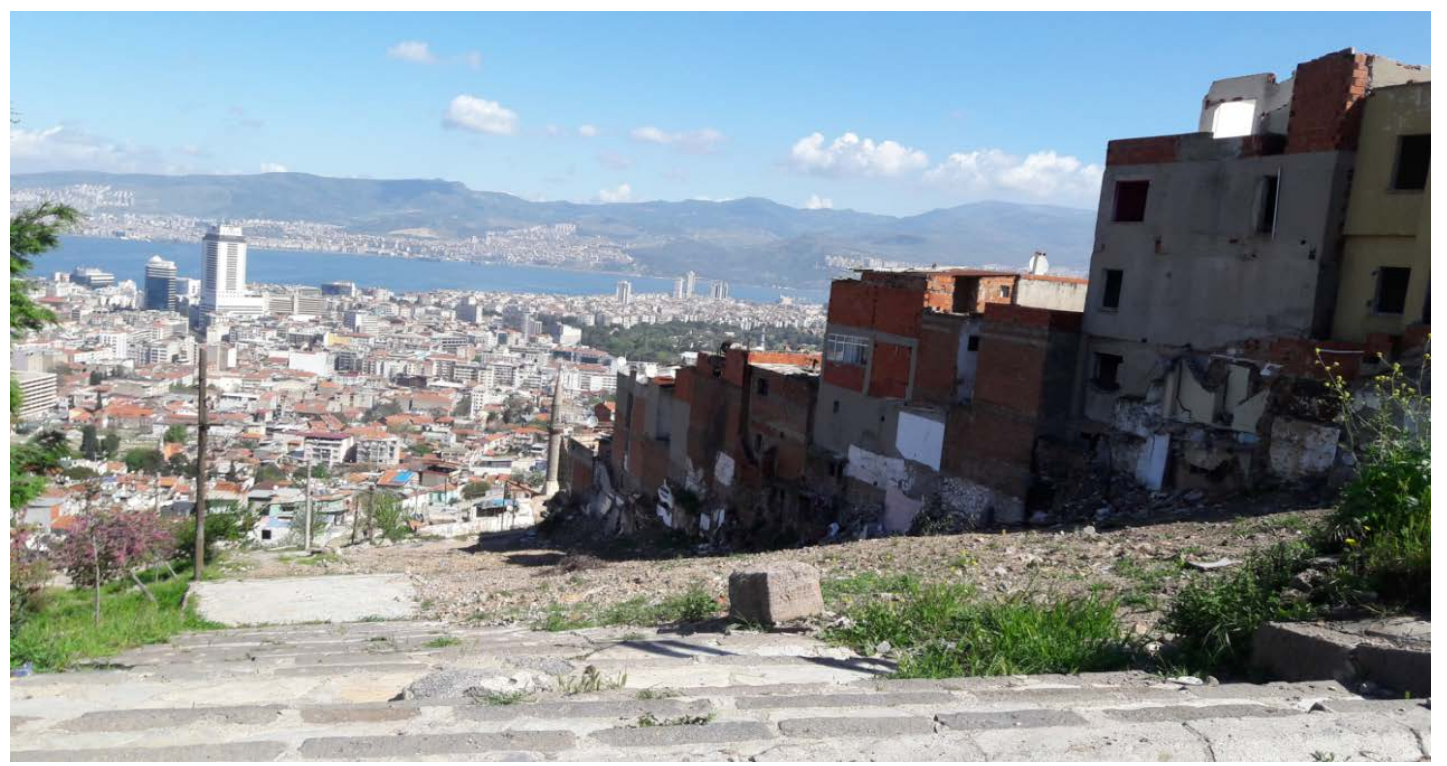

Fotoğraf 5. Kadifekale 'de yıkım yapılmış bir alan 


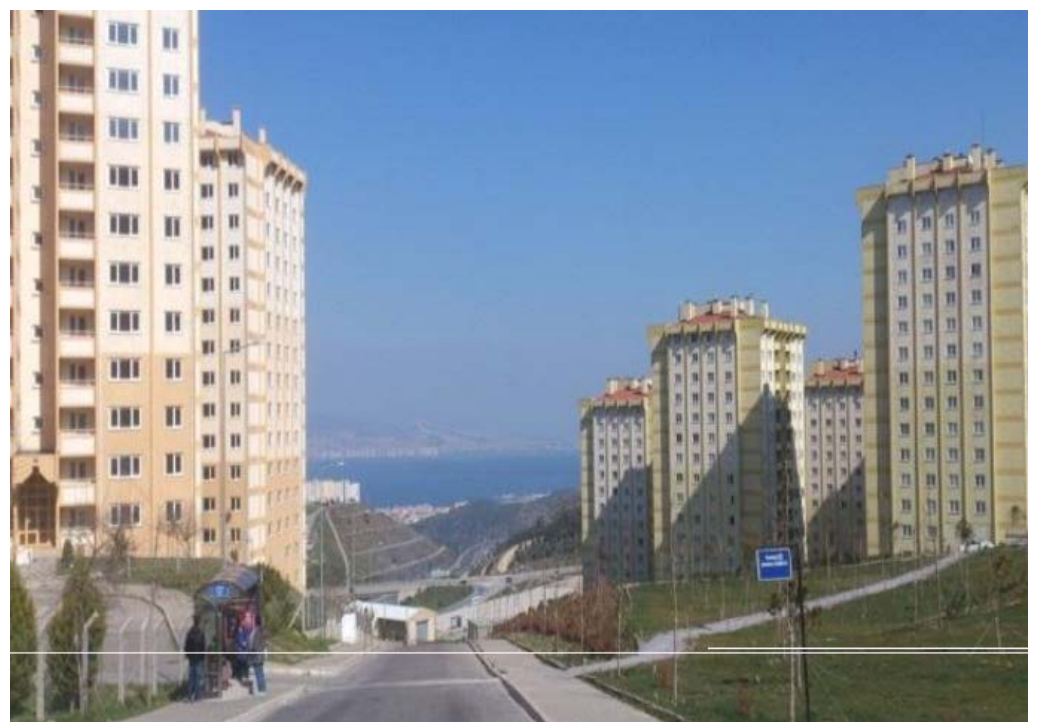

Fotoğraf 6. Uzundere Toplu Konutları (Mirioğlu, 2013, 222)

\section{Kadifekale ve Uzundere Yerleşim Alanlarında Görünmeyen Sınırlar}

Çalışma kapsamında ilk olarak Kadifekale Kentsel Dönüşüm Projesi öncesinde, Kent ile Kadifekale arasında var olan görünmeyen sınırlar makro ölçekte ele alınırken mikro ölçekte ise Kadifekalelilerin kendi içinde yarattıkları görünmeyen sınırlar tartışılmıştır. İkinci aşamada ise kentsel dönüşüm projesi sonrasındaki durum yine makro ve mikro ölçekte ele alınmıştır.

\subsection{Kentsel dönüşüm projesi öncesi görünmeyen sınırlar}

Kadifekale coğrafi olarak şehrin kalbinde yer almasına ve Konak Meydanı, İzmir körfezi gibi kentin önemli simge mekânları ile görsel bir iletişim halinde olmasına rağmen kentten kopuk ve içe dönük bir yerleşim alanıdır (Kılıç, 2016: 135). Bir zamanlar prestijli bir konuma sahip olan Kadifekale Mahallesi, zaman içinde çöküntü alanı haline gelmiş ve kent ile arasında görünmeyen sınırlar inşa edilmiştir. Bölge fiziksel anlamda çok net sınırlarla çevrili olmasa da sosyo-ekonomik anlamda toplumun geri kalanıyla arasında derin sınırlar mevcuttur.

Kadifekale 'de sınırları inşa eden ve besleyen en önemli etmenlerden biri göçtür. 1950'lerden sonra kırsaldan kente doğru yaşanan yoğun göç ile kentlerdeki terkedilmiş binalar göçmenler tarafından geçici mesken olarak kullanılmıştır. Göçmenlerin çoğunluğunu Kürt kökenli vatandaşlar oluşturmaktadır (Karayiğit, 2005: 7). Bu vatandaşlar 1980'lerde ekonomik nedenlerle Kadifekale 'ye göç etmiş ancak 1990'lardan itibaren PKK ile güvenlik güçleri arasında yaşanan çatışmalar sonucu zorunlu bir göç süreci yaşanmıştır. Bu göçlerle birlikte başta türdeş özellikler gösteren kentsel toplumsal yapıda toplumsal ve mekânsal eşitsizlik durumu ortaya çıkmıştır. Göçe bağlı olarak kentte oluşan sosyo-ekonomik dengesizlikler, sınıfsal ayrım, işsizlik, yoksulluk, yoksunluk sınırların oluşmasına, değişip dönüşmesine sebep olmuştur. Bu durum kentin görünümünü, dolaşım örüntülerini ve yaşam pratiklerini değiştirmektedir. Göç sürecinin ev sahibi toplumda kıt kaynakları bölüşüm ve eğitim gibi kamu hizmetlerinin sunulmasını içeren sonuçları vardır (Güzel, 2013: 2). Bu durum, göçmenler ile ev sahibi toplumun kaynaşması önünde engel oluşturmakta ve görünmeyen sınırları beslemektedir. 
Kadifekalelilerin çoğunluğunu oluşturan ve yerleşim alanının "Mardinkale" olarak anılmasına sebep olan Mardinliler hemşerilik bağıyla birbirleriyle iletişim halinde olup dışa fazla açılmamış ve memleketlerinde alışık oldukları düzeni Kadifekale'de de devam ettirmeye çalışmışlardır. Mahalle içerisinde mevcut güçlü sosyal dayanışma ağları bireylerin kendilerini güvende hissetmelerini ve kültürel özelliklere sahip yaşam pratiklerini sürdürerek kimliklerini korumalarını sağlamıştır. Sevinç ve üzüntülerin paylaşımı, yardımlaşma ve dayanışma gibi olumlu yönleri olan bu bir aradalık durumu mahalle dışında yaşamı idame ettirme korkusu, güvensizlik ve savunmasızlık duygusuyla ilişkilidir. Sakinlerinin birbirini tanıdığı Kadifekale, bu özelliği sayesinde aidiyet duygusunun geliştirilmesine katkı sağlayıp, kente ve kentteki "yabancılara" karşı hissedilen tedirginliği azaltmaktadır. Barındıkları gecekonduların bir gün yıkılabileceğini bilmenin oluşturduğu geçicilik duygusu dahi aidiyet hissini zedelememiş ve Kadifekale zamanla göç edenlerin mekânı haline gelerek "Kadifekaleli" diye adlandırılan ve sınırlar tarafından tanımlanarak korunan bir kimliği inşa etmiştir (Kılıç ve Göksu, 2018: 208).

Kadifekalelilerin toplu olarak aynı bölgelerden göç etmeleri ve kendi içlerine kapalı bir yaşam sürdürüp diğer kentlilerle etkileşim içine girmemeleri, kentli olma süreçlerinin uzamasına sebep olmuş ve bunun sonucunda da sınırlar pekişmiştir. Göçmenlerin, hemşerilik ve akrabalık bağıyla birbirlerine bağlı oluşu, iş ve konut edinmeyi kolaylaştırması yönünden olumludur ancak geldikleri bölgelerin alışkanlıklarını aynen devam ettirmeleri nedeniyle ne köylü ne de kentli olabilmişlerdir.

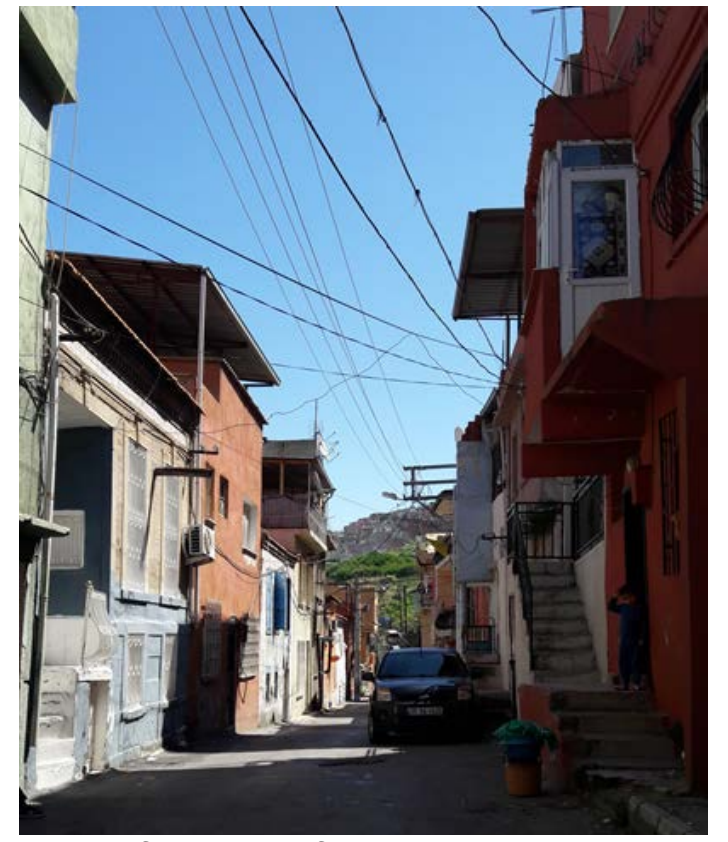

Fotoğraf 7. Kadifekale'de eğime dik bir sokaktan görünüm

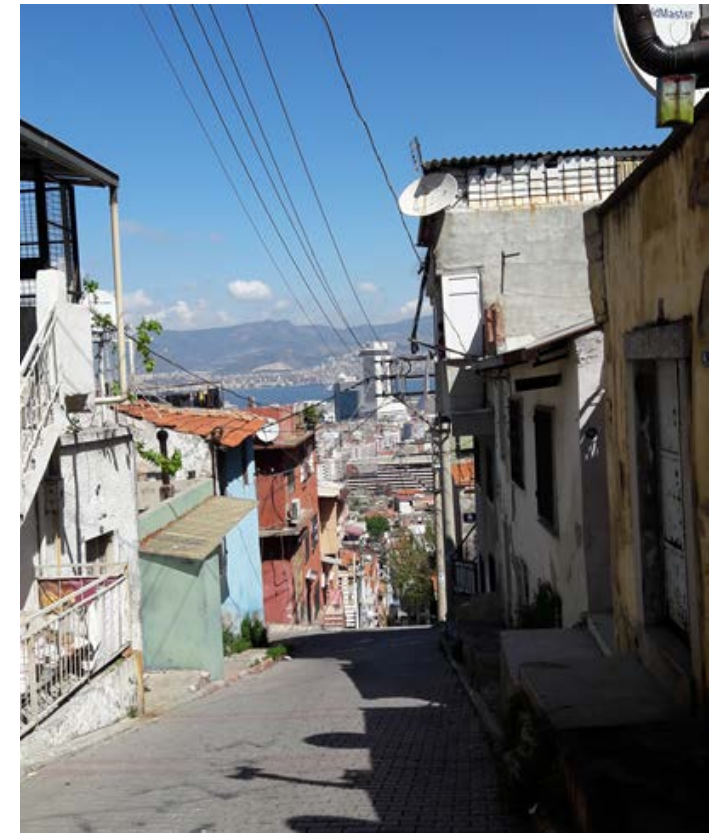

Fotoğraf 8. Kadifekale'de eğime paralel bir sokaktan görünüm

Kadifekale'de yapılan enformel görüşmeler sırasında edinilen bilgilere göre bölgede yaşamaya devam eden Kadifekaleliler dar sokaklara, konutlar arası mesafenin azlığından dolayı güneşten yeterince faydalanamama gibi yetersiz yaşam koşullarına rağmen (Fot. 7, Fot. 8) yaşadıkları çevreden memnunlar. Ayşe B. (35), daha iyi koşullara sahip olduğu düşüncesiyle Uzundere toplu konutlarına gönüllü olarak taşınan komşularının pişman olduğunu belirtmiştir (Kişisel iletişim, 15 Nisan 2019). Zamanlarının çoğunu açık alanda geçirmeye alışmış kişiler için müstakil konut oldukça önemli bir yer tutarken buna ek olarak Kadifekale'de bulunan gecekonduların, genellikle yüksek gelirli ailelerin konutlarında rastlanan deniz manzarası mevcuttur (Fot. 9, Fot. 10, Fot. 11). Bu ve benzeri birçok nedenden dolayı Kadifekaleliler gündelik 
yaşam pratiklerine uyan ve kendilerini ait hissettikleri bu bölgeden ayrılmak istememektedir.

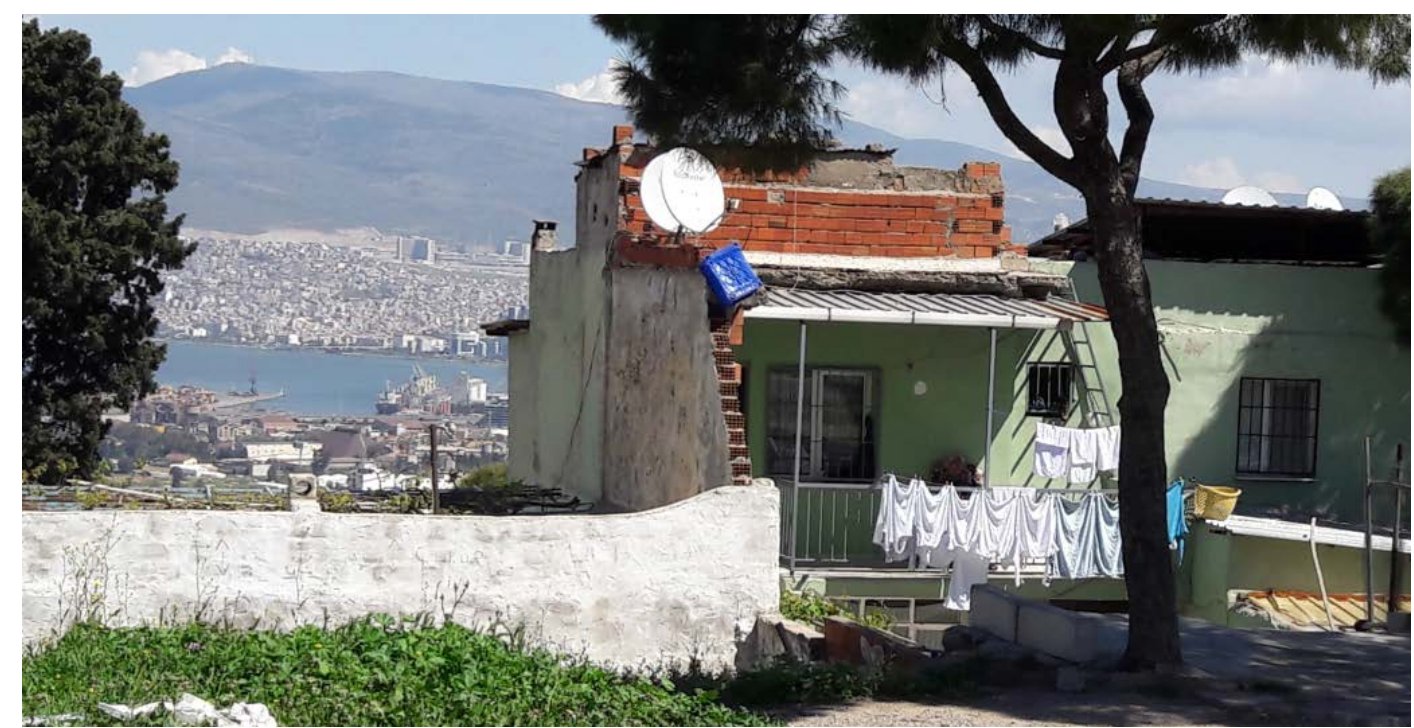

Fotoğraf 9. Deniz manzaralı bir gecekondu

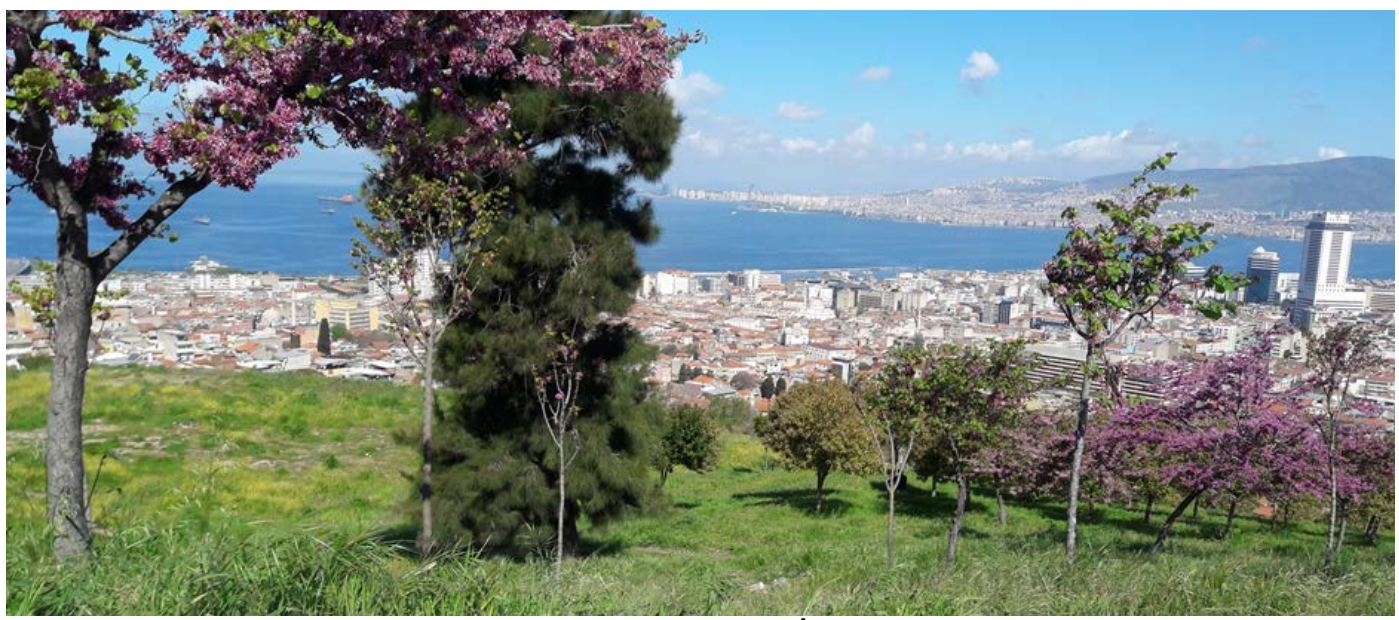

Fotoğraf 10. Kadifekale 'den İzmir Manzarası

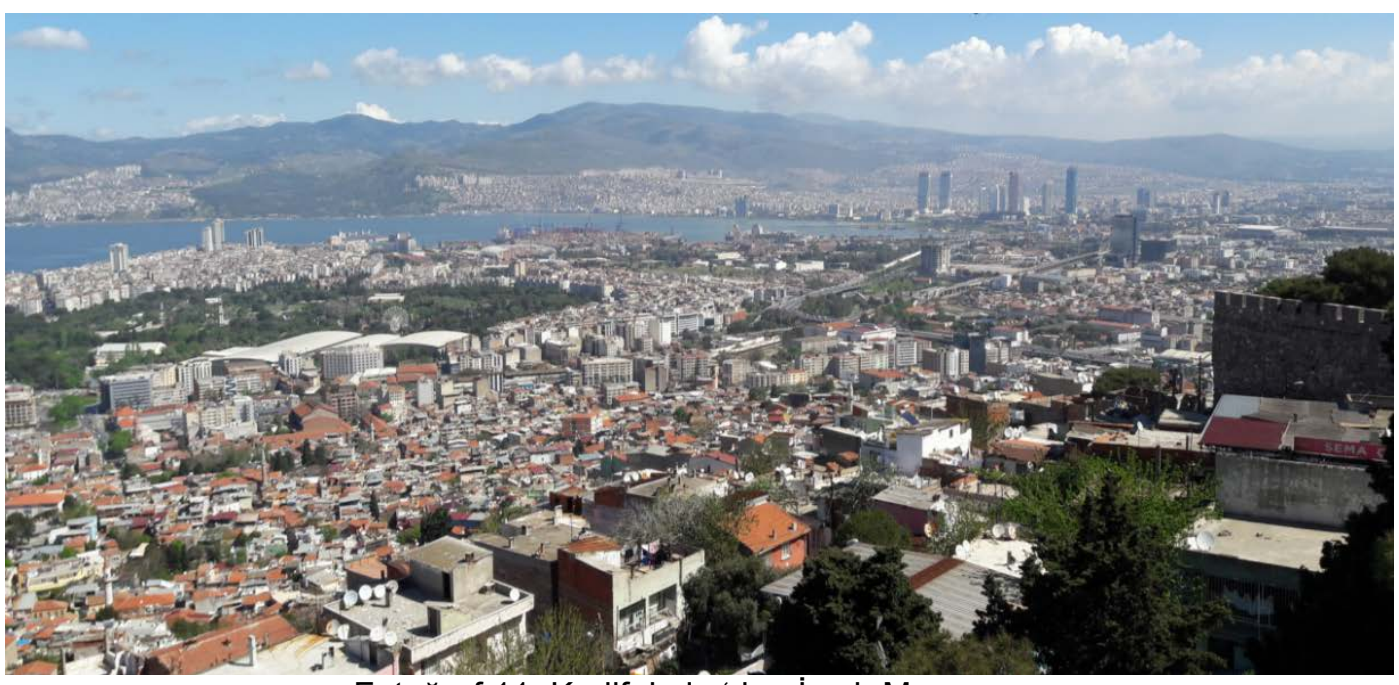

Fotoğraf 11. Kadifekale 'den İzmir Manzarası 
"Kentli" ile "Kadifekaleli" arasındaki sınırları besleyen bir diğer faktör ise göçmenlerin yerleşme şeklidir. Gecekondular başta geçici bir mesken olarak düşünülürken zamanla bu durum değişmiş ve kalıcı hale gelmiştir. "Kentli" başta yoksulluktan ve barınma intiyaçlarını geçici olarak karşılamak için enformel yerleşim alanlarında barındığını düşündüğü gecekonduluya acırken, 1990'lara gelindiğinde gecekonduluya artık haksız kazanç sahipleri olarak bakılmaktadır. Bu imajın oluşmasında siyasi tutum da etkili olmuştur. Oy devşirme amacı ile çıkarılan imar afları nedeniyle gecekondular başlarda meşru görülürken, artık rant ekonomisinin bel kemiğini oluşturmaktadır (Buğra, 2008; Bozkulak, 2005, aktaran Aksoy, Kocataş, 2017: 281). Orta sınıf İzmirlilerin, Kürt Kökenli vatandaşlara yönelik algısı üzerine yapılan bir araştırmada olumsuz algıyı besleyen bir diğer koşulun göçmenlerin çoğunlukla enformel sektörlerde çalışıyor olması ve bu nedenle haksız kazanç sağladıkları düşüncesidir (Saraçoğlu, 2009: 23). Haksız kazançla bağdaştırılan ve 'varoş' kavramı altında değerlendirilen gecekondulu giderek suç ve şiddetle bağlantılı olarak görülmeye başlanmış ve toplumdaki hâkim imaj 'cahil köylü 'den çok, "kentle bütünleşme niyetinde olmayan, topluma karşı tehlike oluşturan ve suça yatkın öteki" olmaya başlamıştır. Göçle birlikte gelen "yabancı" ya karşı duyulan tedirginliğin artması "öteki"nin düşman olarak görülmeye başlanmasıyla "kentli" tehlikeye karşı kendince önlemler alarak bir dizi sınır inşa etmiştir. Kent yaşantısını bozmakla suçlanan gecekondulular, "varoşlu" şemsiyesi altında şiddet ve toplumsal düzensizlikle bir araya getirilmekte ve "sakıncalı öteki" olarak tanımlanmaktadırlar (Erman, 2001: 997). "Öteki" ile "tehlike"nin zihinlerde özdeşleşmesi, rant değeri yüksek bir bölge olan Kadifekale'nin "sterilleştirilmesi"ne haklı bir gerekçe daha sunmaktadır.

"Öteki" kavramı aslında "kimlik" kavramının içerdiği paradoksa içkindir. Bu paradoks kimliğin kendini tanımlamak için bir ötekinin varlığına olan intiyacıdır. Latince idem (aynı) kökünden türetilen identité /identity kelimesi bir özdeşliği, ifade eder (Kılıçbay, 2003: 155). Connolly'e göre, "Kimlik varolmak için farklılığa gereksinim duyar ve kendi kesinliğini güven altına almak için farklılığı ötekiliğe dönüştürür" (1995: 92, 93). Günümüzdeki postmodern söylem, çok kültürlü toplumsal yaşam vaad etmekle beraber, aslında kendi içinde bölünmeyi, kutuplaşmayı ve eskisine nazaran çok daha şiddetli bir şekilde "biz" ve "öteki" ayrımını getirmiştir (Selçuk 2012,94). Postmodernizm sözüm ona marjinalleştirilmiş kimliklere ses verme kisvesi altında, zaten dengesiz iktidar ilişkilerinin hâkim olduğu dünyada, bu farklı sesleri güçten yoksun kılmaktadır (Harvey, 2003: 138).

Ötekileştirmeyi, dolayısıyla da görünmeyen sınırları, besleyen unsurlardan biri medyadır. Medyada yer alan söylemler dışlayıcı süreçleri pekiştirmekte önemli bir rol oynamakta ve mahallenin suç ile özdeşleşen kötü namıyla mekansal damgalama şiddetlenmektedir. Kadifekale sakinleri, yalnızca burada yaşıyor olmaktan dolayı suça yatkın görülmektedir. Örneğin, Gazetemizmir'in 07 Ekim 2017 tarihli “iş̧te Türkiye'nin En Tehlikeli Mahalleleri" başııkı yazısında Kadifekale de yer almaktadır. Yazıda, İzmir'in en güzel manzaralarından birinin Kadifekale'den izlenebileceği belirtilmiş ancak polisin dahi bölgeye kolay kolay giremediğinin altı çizilmiştir (URL-4). Günümüzün en etkili sosyal medya mecralarından biri olan Youtube'da ise "İzmir'in En Tehlikeli Mahallesi Kadifekale Pagos'a Girdik!" adlı videoda kişilere, sizce İzmir'in en tehlikeli mahallesi neresidir sorusuna insanların çoğu Kadifekale cevabını vermiştir (URL-5). "İzmir'in En Tehlikeli 10 Semt'i" isimli videoda ise liste de ilk sırayı Kadifekale almaktadır (URL-6). Bu ve bunlara benzer birçok videoda bölgeyi suçla ve tehlikeyle özdeşleştiren bir söylem hakimdir. Yine çok kullanılan sosyal mecralardan olan Ekşi Sözlük'te kişiler Kadifekale ile ilgili deneyimlerini aktarırken çoğunlukla olumsuz bir anlatım kullanmışlardır. Beestar rumuzlu kullanıcı 01.12.2019 tarihli paylaşımında Kadifekale'den "döndüğümüzde arabamız altımızda mı acaba diye kontrol ettiğimiz, hemen girişindeki karakolda panzerler bekleyen İmir semti. Evet şehir ayaklarınızın 
altında ama korkuyla manzara izlenmiyor ki” şeklinde bahsetmektedir. Travma adlı kullanıcı ise 26.05.2003 tarihli yazısında "son senelerde biraz tehlikeli ve yaşanmaz hale gelmiş olan İzmir in eski ve güzide bir semtidir, kaleden mükemmel bir körfez manzarasına ulaşılabilir. Bilmeyenlerin gece küçük gruplar halinde gitmemesi tavsiye olunur" ifadeleri yer almaktadır (URL-7). Bunların yanısıra; Eroğlu (2019, 56), "Relocation from an inner-city neighborhood to peripheral mass housing: from Kadifekale to Uzundere, İzmir" adlı tezinde ve Çetin (2011,73-75), "Kentiçi bir çöküntü alanı örneği Kadifekale'de mekan sosyolojisi denemesi" isimli makalesinde de bölgenin "tehlikeli" olarak algılandığına vurgu yapılmıştır. Kadifekale ile ilgili olumsuz söylemler diğer "kentli"lere korku salarak bölge sakinlerinin damgalanmasına sebep olmaktadır. Özellikle Kadifekale üzerinde yoğunlaşan bu korku söyleminin bölgenin sahip olduğu rant değeri ve Kadifekale Kentsel Dönüşüm projesi ile ilgili olup olmadığı ayrıca tartışılmalıdır. Bu söylemlere devam edildiği müddetçe Kadifekaleliler, sosyal dışlanmaya daha çok maruz kalarak suça yönelme intimalleri daha da artmaktadır. Kısır bir döngü halini alan bu durum birbirini besleyerek devam etmektedir.

Mikro ölçekte bakıldığında ise görünmeyen sınırların Kadifekaleliler ile "kentli" arasında sınırlı kalmayıp Kadifekalelilerin de kendi içinde yeni sınırlar inşa ettikleri görülmektedir. Bu sınırlardan bir kısmı bölgeye ilk göç eden ve görece olarak daha yüksek gelir olanaklarına kavuşan grup ile sonradan göç eden kuşak arasında belirir. Zamanla "gecekondu sahipleri" ile "gecekondu kiracıları" şeklinde ayrışmalar oluşmaya başlar. Başka bir ayrışma ise batıdan ve doğudan göç edenler arasında ya da farklı etnik kökenlere sahip bireyler arasında olmaktadır (Uslu, 2012: 27).

Başta daha heterojen bir yapıya sahip olan Kadifekale, 1980'lerden sonra doğudan, özellikle de Mardin'den, yapılan yoğun göçlerle daha homojen bir yapıya sahip olmuş ve birçok etnik grup azınlıkta kalmıştır (Karayiğit, 2005: 7). Örneğin, çoğunlukla eğlence sektöründe çalışan Roman vatandaşlar, eğlence merkezlerine yakın olan Kadifekale 'de hayatlarını sürdürürken, yaşanan göçlerle birlikte yeni gelen grupla aralarına görünmeyen sınırlar inşa edilmiştir. Yaşanan ayrışma sonucu Roman vatandaşların birçoğu bölgeyi terk etmiş ve mahalledeki Roman vatandaşlar azınlık durumuna düşmüştür. Kısacası Kürt ve Roman vatandaşlar arasında yaşanan gerilim sonucunda Kürt vatandaşlar bir nevi baskın çıkmıştır. Çok kültürlü bir yapıdan, gettolaşan bir duruma evrilen mahallede etnik/sınıfsal/kültürel bir ayrışma noktası olarak Kürt-Çingene ayrımı doğmuştur. Bu gerilim özellikle mahallenin kılcal damarlarını oluşturan sokaklar düzeyinde daha sert ve belirgin bir şekilde ortaya çıkmaktadır. Romanların yaşadığı sokaklar diğerlerinden ayrışmış ve bu ayrışma bölgelerde işlenen suçların dahi farklılaşmasında etkili olmuştur. Herhangi bir istatistiksel veri olmamasına rağmen, sahada yapılan enformel görüşmelerde, Kürt kökenli vatandaşların uyuşturucu satıcılığı ile, Roman vatandaşların ise fuhuş ve hırsızlık ile bağdaştırıldığı tespit edilmiştir. Romanların fuhuşa karışmış oldukları düşüncesi mahallede yaşayan ve geleneksel bir yaşantıya sahip olan Kürt aileleri rahatsız etmekte, dolayısıyla Kürt-Roman ayrışmasını beslemektedir. Daha muhafazakâr yapıda olan Kürt vatandaşlarla daha rahat bir yaşam sürdüren Roman vatandaşlar arasında, kadının kamu alanlarını kullanımı gibi gündelik yaşam pratiklerinde büyük farklar bulunmaktadır. Çocukluğu Kadifekale 'de geçen Bilal E. (32) sokaklar arasındaki bu ayrımın çocukluğunda daha da net sınırlarla belirlendiğini ifade etmiştir (Kişisel iletişim, 15 Nisan 2019). Bu durum Roman ve Kürt vatandaşlara ait sokakların arasındaki görünmeyen sınırların, çocuklar tarafından bile hissedildiğini göstermektedir. Benzer durumun birçok gecekondu bölgesinde, örneğin; İstanbul, Esenler'de de yaşandığı ve Roman vatandaşların yaşadıkları sokakların diğerlerinden ayrıştığı görülmektedir (Erman ve Eken 2004, 64). Kısacası, kentli için "öteki" olan gecekondulular, kendi "öteki"sini yaratarak kendi içinde de hiyerarşik olarak 
bölünmektedir. "Öteki”lerin hiyerarşisi dünyanın pek çok yerinde de görülebilmektedir. Örneğin, Du Bois (1899), Philedelphia gettolarında yaptığı incelemeler sonucunda öteki olarak nitelendirilen grupların kendi içinde de ötekiler tanımladığını ve homojen bir yapının bulunmadığını gözlemlemiştir. Kentli tarafından ise bu farklılıklar yok sayılarak gecekondu halkı homojen bir grupmuş gibi algılanmış ve geneli "varoş" ifadesiyle tanımlanmıştır (Erman,2001:996).

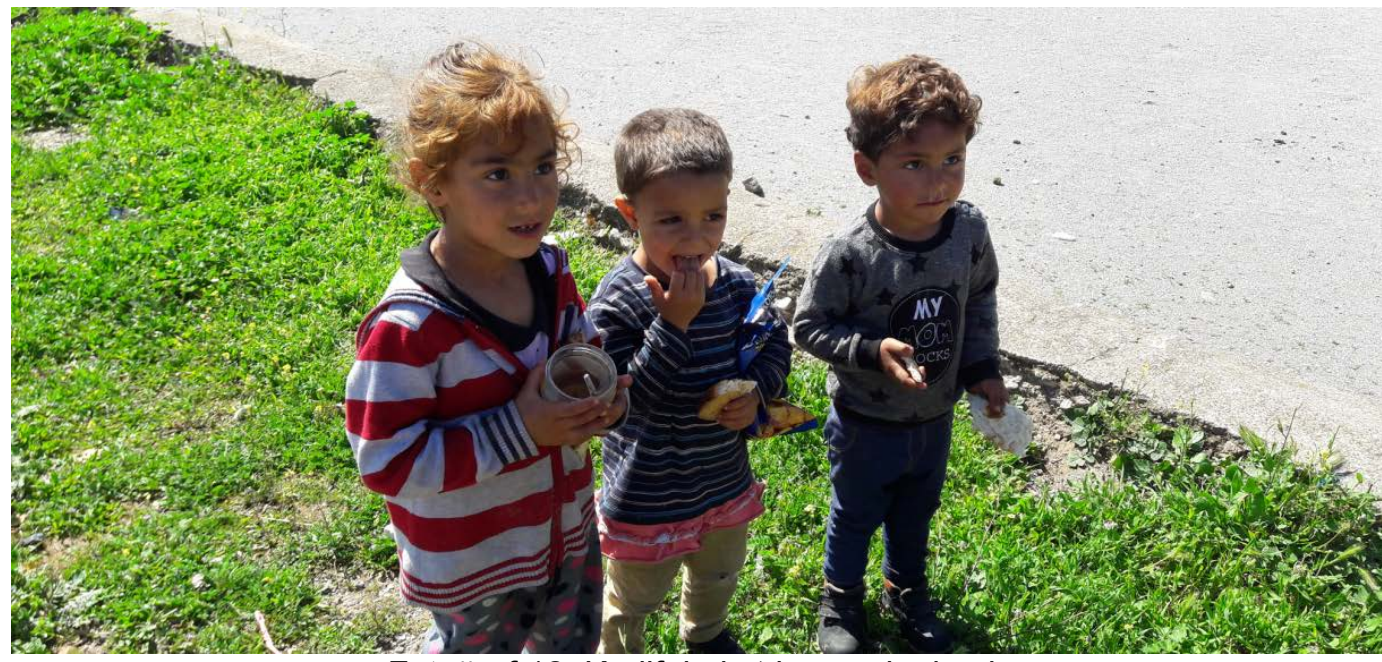

Fotoğraf 12. Kadifekale 'de çocuk olmak

\subsection{Kentsel dönüşüm projesi sonrası görünmeyen sınırlar}

Kentsel dönüşüm projesi öncesinde, her ne kadar Kadifekale ile kent arasında görünmeyen sınırlar mevcut olsa da kentle kurdukları ilişkiler sayesinde kent içinde var olmayı ve kentte görünür olmayı başaran Kadifekaleliler, kentsel dönüşüm projesi sonrasında kentin dışına itilerek bu şanslarını da kaybetmişlerdir. Kentsel dönüşüm projesi sonrasında Kadifekaleliler ile kent arasında var olan görünmeyen sınırlara bir de fiziksel sınırlar eklenmiştir (Şekil 3). Uzundere Toplu Konut alanı kent merkezinden oldukça uzakta yer almakta ve kent ile arasından geçen otoban sadece fiziki bir öge değil, kentle olan ilişkiyi ayıran temsili bir sınır olarak kendini göstermektedir. Mustafa D. (30) bu durumu "Biz İzmir'den Ayrıyız. Çevre otobanının üzerindeki o köprü bizi İzmir'den ayırıyor, iklimimiz dahi değişiyor" şeklinde belirtmektedir (Kılıç ve Göksu, 2018: 211).

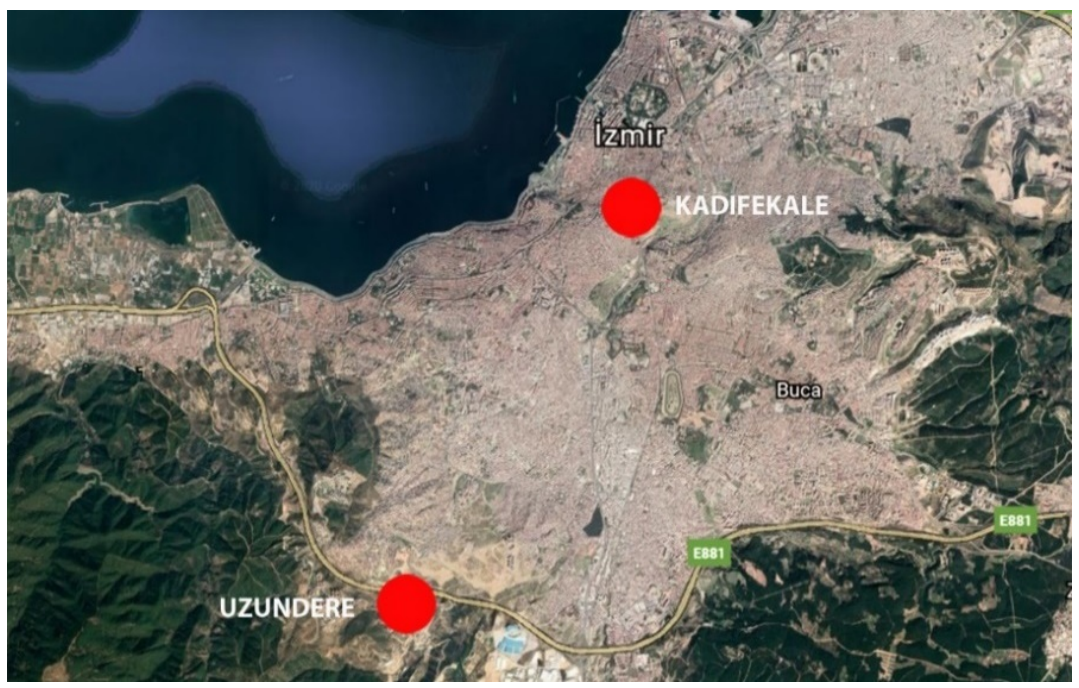

Şekil 3. Uzundere Yerleşim Alanının Kadifekale'ye göre Konumu 
Yeni yerleşim yerinin kent merkezine oldukça uzak olması sosyo-ekonomik açıdan da birçok olumsuz sonuç doğurmuş ve Kadifekalelilerin yoksullaşması ile görünmeyen sınırlar daha da belirginleşmiştir. İşyerleri çoğunlukla Kadifekale ve Konakta olan Kadifekale sakinleri işyerlerine yürüyerek dahi ulaşım sağlayabilmekteyken, gelir düzeyi zaten düşük olan Kadifekalelilerin, iş yerlerine ve kent merkezine olan ulaşım masraflarının artması ve ekstra olarak Uzundere'de aidat ödüyor olmaları gurubun yaşam koşullarını daha da zorlaştırmıştır (Mirioğlu, 2013:195).

Görünmeyen sınırları pekiştiren bir diğer etken ise kent merkezindeki yaşam alanlarından kentin çeperine zorunlu olarak göç etmeye zorlanan bireylerde artan “öteki”lik ve dışlanmışlık duygusudur. Dezavantajlı bir grubu temsil eden Kadifekaleliler sosyal, ekonomik ve mekânsal alanda çok boyutlu bir sosyal dışlanmaya maruz kalmışlardır. Zihinlerde var olan olumsuz algının sonucunda kent içinde yer değiştirebilme özgürlüğü kısıtlı olan bu bireylere göre kendilerine Uzundere'de sunulan konutlara razı olmak tek seçenek gibi görünmekte ve bu zorunlu yer değiştirme süreci aidiyet duygusunu zedelemektedir. Alanda yapılan enformel görüşmelerde edinilen izlenime göre kentsel dönüşüm projesinin asıl amacının Kadifekale'de yaşayanların kentten izole edilmesi olarak algılandığı görülmüştür.

Mikro ölçekte bakıldığında ise kentsel dönüşüm projesi sonrasında Uzundere Toplu Konut alanına yerleşen Kadifekale sakinlerinin burada da farklı bir ayrışmaya tabii olduğu görülmektedir. Yeni yerleşim alanında yer alan iki farklı konut tipinden biri 75 diğeri ise 95 metrekarelik dairelerdir. Bu iki daire tipinde Kadifekale'den gelenler oturmaktayken daha büyük dairelerde (120 metrekare) Kadifekale Dönüşüm Projesi ile ilgisi olmayanlar ikamet etmektedir. Sakinlerce "Yeşiller" olarak adlandırılan bu bloklar, binaların rengine atıf olsa da aynı zamanda "Yeşiller"de oturanların göreli sosyal statüsüne "elit" bir gönderme içermektedir (Kılıç ve Göksu, 2018: 214). Bu durum ekonomik sebeplere dayalı bir "sosyal statü" farkı yaratmakla birlikte Kadifekalelilere karşı zihinlerde var olan algı da bu ayrımı beslemektedir. Suçluların mahallesi olarak anılan Kadifekale'de yaşayan kişilerin, TOKI evlerinde diğer bireylerle beraber ikamet etmeye başlaması, diğer bireyler tarafından tedirgin edici bir durum olarak algılanmıştır (Özer vd., 2013). Kısacası, Uzundere'ye gelen Kadifekaleliler mekan değiştirmiş olsa da kendilerine atfedilen imaj hala zihinlerdedir, dolayısıyla mekan değişse bile sınırlar yok olmamış sadece yer değiştirmiştir.

Kadifekaleliler kendi kimlikleriyle özdeşleşmiş olan ve "Mardinkale" olarak da anılan Kadifekale'ye duydukları aidiyet duygusunu yeni yerleşim alanları olan Uzundere'de henüz inşa etmemişlerdir. Aidiyet hissi, içinde yaşanılan çevrenin bireylerin yaşam pratiklerine uygunluğundan da beslenmektedir, dolayısıyla Kadifekalelilerin müstakil olan ve açık mekanlar içeren konut tipolojisinden ayrılarak alışkanlıklarıyla ters düşen apartman dairelerine sıkışıp kalmaları yaşadıkları mekanı benimsemeleri ve aidiyet duygusu geliştirmelerini önleyen bir faktördür. Müstakil konutlarında zamanlarının çoğunu açık alanda geçirerek yaşamaya alışmış olan Kadifekaleliler yaşam pratikleriyle hiç uyuşmayan apartman dairelerine geçtiklerinde bir uyum problemi yaşamışlardır. Düzen ve alışkanlıklarından koparılarak şehrin dışına itilen bu insanlar Kadifekale'den ayrılmakla kültürlerine özgü yaşam pratiklerini ve kimliklerini yavaş yavaş kaybetmektedir.

\section{Değerlendirme ve Sonuç}

Günümüzde kent planlamasının yerini alan kentsel dönüşüm projeleri, farklı toplumsal gruplar arasındaki ayrımı daha da tanımlı hale getirerek grupların birbirleriyle olan iletişimlerini azaltmakta ve aralarında yeni sınırlar inşa etmektedir. Bireyleri toplu halde 
kentin dışına tecrit etmek, bir arada olmanın sağlayacağı aşinalıkla bütünleşen bir toplum yerine, birbirinden koparıldıkça sınırları keskinleşen, parçalanmış bir toplum oluşturmaktadır. Kent, toplumsal ayrışmalarla birlikte bütünlüğünü yitirmekte ve bölgeler arası farklılıklar büyüyerek sınırlar daha da tanımlı hale gelmektedir. Kadifekale örneğinde, ayrışmaların sadece "Kentli" ile Kadifekaleliler arasında sınırlı kalmadığı ve Kadifekalelilerin de kendi içinde görünmeyen sınırlar inşa ettiği görülmektedir. Dışarıdan bakan gözün homojen kabul edip topyekün "varoş" olarak nitelendirdiği Kadifekalelilerin, kendilerine uygulanan ötekileştirmeyi kendi içinde devam ettirerek kendi "öteki” sini yarattığı görülmektedir.

Kadifekale Kentsel Dönüşüm Projesi öncesinde, eğreti bir şekilde de olsa kentle ilişki kurarak kentte görünür olmayı başaran Kadifekaleliler, kentsel dönüşüm projesi sonrasında bu şanslarını da yitirmiştir. Kadifekale ile kent arasında her ne kadar görünmeyen sınırlar mevcut olsa da kentsel dönüşüm projesiyle birlikte bu sınırlara eklenen fiziksel sınırlar durumu daha da olumsuz etkilemiştir. Kent ile aralarından geçen otoban bu durumun somut bir örneğidir. Ayrışmayı ve dışlanmayı daha görünür kılan bu uygulamaların asıl amacı kişilere daha sağlıklı barınma koşulları sunarak onları daha "kentli" yapmak iken, kentten dışlanmış olmaları onları "kentli" olmanın aksine kentten koparmıştır. Kentten uzakta konumlanan Uzundere, kişilerin ekonomik koşullarını daha da zorlaştırarak yoksulluklarını pekiştirmiş ve sınırları keskinleştirmiştir. Kadifekalelilere yönelik olumsuz algı değişmediği için Kadifekaleliler sınırları da beraberlerinde Uzundere'ye getirmiş hatta burada yeni sınırlarla da karşılaşmıştır. Kısacası, kentsel dönüşüm projesi sonrasında sınırlar yok olmamış sadece yer değiştirmiş hatta derinleşmiştir.

\section{Kaynaklar}

Akkar, Z. M. (2006) Kentsel dönüşüm üzerine Batı'daki kavramlar, tanımlar, süreçler ve Türkiye. Planlama, 2, 29-38.

Aksoy, E. ve Kocataş, Ö. G. (2017) Gecekondu Alanlarında Uygulanan Kentsel Dönüşüm Projelerinin Meşruiyet Zemini Olarak Yoksulluk ve Suç. Karadeniz Teknik Üniversitesi Sosyal Bilimler Enstitüsü Sosyal Bilimler Dergisi, 7(14), s.275-295.

Connolly, W. E. (1995) Kimlik ve Farklılı: Siyasetin Açmazlarına Dair Demokratik Çözüm Önerileri. İstanbul: Ayrıntı Yayınları.

Cruz, T. ve Boddington, A. (1999) Architecture of the borderlands, Academy Editions, 1999.

Çetin, İ. (2011) Kentiçi bir çöküntü alanı örneği Kadifekale'de mekan sosyolojisi denemesi. Sosyoloji Dergisi, 25, s.53-80.

Du Bois, W. E. B. (1899) The Philadelphia Negro. Reprinted in R. LeGates and F. Stout (eds), The City Reader.

Erman, T. (2001) The politics of gecekondu (squatter) studies in Turkey: the changing representations of rural migrants in the academic discourse. Urban Studies 38(7), 9831002. 
Erman, T. ve Eken, A. (2004) The "Other of the Other" and "unregulated territories" in the urban periphery: Gecekondu violence in the 2000s with a focus on the Esenler case, İstanbul, Cities. 21(1), s.57-68.

Eroğlu, E. (2019) Relocation from an inner-city neighborhood to peripheral mass housing: from Kadifekale to Uzundere, Izmir. Yüksek Lisans Tezi. Ortadoğu Teknik Üniversitesi, Sosyal Bilimler Enstitüsü, Ankara.

Göncü, H. (2013) Smyrna Akropolü (Kadifekale) yapı evreleri. Yüksek Lisans Tezi, Dokuz Eylül Üniversitesi, Sosyal Bilimler Enstitüsü, İzmir.

Görgülü, Z. (2009) Kentsel Dönüşüm ve Ülkemiz. TMMOB, İzmir Kent Sempozyumu, 08-10 Ocak 2009, s: 767-780, İzmir.

Güzel, S. (2013) Göçmen Çocuklar ve Denizli'de Yaşam Koşulları. Hacettepe Üniversitesi Sosyolojik Araştırmalar Dergisi, 51, s.1-36.

Harvey, David (2003) Postmodernliğin Durumu. İstanbul: Metis Yayınları.

Karayiğit, A. (2005) Kadifekale'nin sosyo-ekonomik profili ve sorunları. İzmir Ticaret Odasi Yayını.

Kılıç, E. M. (2016) Neoliberal politikalar çerçevesinde Türkiye'de kentsel dönüşüm ve kentsel mekânı yeniden anlamlandırmada sözlü tarih bilgisi: İzmir-Kadifekale kentsel yenileme projesi örneği. Doktora Tezi. Dokuz Eylül Üniversitesi, Fen Bilimleri Enstitüsü, İzmir.

Kılıç, E. M. ve Göksu, A. E. (2018) Bir Kentsel Dönüşüm Deneyimi: KadifekaleUzundere İkileminde Bireysel Öyküler Üzerine Düşünmek. Planlama, 28(2), s.201-217.

Kılıçbay, Mehmet Ali (2003) "Kimlikler Okyanusu", Doğu-Batı, "Kimlikler". Ankara: Doğu-Batı Yayınları, Sayı: 23, s. 155 - 159.

Lang, J. (1987) Creating architectural theory: The role of behavioral sciences in environmental design, Van Nostrand Reinhold, New York.

Marcuse, P. (1999) Walls of Fear, in Ellin, N. (editör) Architecture of Fear. New York, Princeton Architectural Press.

Mirioğlu, G. (2013) İzmir'deki kentsel dönüşüm projeleri üzerinden karşılaştırmalı bir coğrafi analiz: Kadifekale Uzundere örneği. Yüksek Lisans Tezi. Ege Üniversitesi, Sosyal Bilimler Enstitüsü, İzmir.

Mumcu Uçar, Ö. ve Özsoy, A. (2006) Sınır Kavramına Mekânsal Bir Yaklaşım: Bahçelievler Örneği. ITÜDERGisi/a mimarlık, planlama, tasarım, 5 (2), s.11-24.

Özer, Y. E., Yönten, A. ve Yılmaz, F. (2013) A Study About Analyzing the Socio Human Elements of Urban Renewal in Natural Disaster Risky Areas: The Examples of Uzundere TOKI Association of Solidarity and Assistance With TOKI Residents. 8. Kamu Yönetimi Sempozyumu. 
Roberts, P. (2000) The evolution, definition and purpose of urban regeneration. Peter Roberts ve Hugh Sykes (der.) Urban Regeneration. London, Thousand Oaks, New Delhi: Sage Publications. 9-36.

Saraçoğlu, C. (2009) İzmirli orta sınıfta Kürt algısı: Mekân, sınıf ve kentsel yaşam. Praksis, 21, s.17-46.

Selçuk, S. S. (2012) Postmodern Dönemde Farklılı̆ın Kutsanması ve Toplumun Parçacıllaştırılması:"Öteki” ve "Ötekileştirme". Sosyoloji Araştırmaları Dergisi, 15(2), 77-99.

Sönmez, B. (2014) Soylulaştırmanın yeni biçimleriyle yerinden edilmeyi yeniden düşünmek. Planlama Dergisi, 24(1), 42-53.

Tekeli, İ. (2018) İzmir Belediyeciliğinde 2004-2018 Dönemi'nin Öyküsü I. İzmir Büyükşehir Belediyesi.

Uslu, L. (2012) Göçmenlerde Yoksulluk Yansımaları: Denizli Örneği. Doktora Tezi. Pamukkale Üniversitesi, Sosyal Bilimler Enstitüsü, Denizli.

\section{İnternek Kaynakları}

URL-1: http://www.eskiturkiye.net/1304/izmir-kadifekale-1870ler Son Erişim Tarihi: 02.11.2020. Erişim Saati: 14:30

URL-2: $\quad$ https://tr-tr.facebook.com/137525849742251/photos/bir-zamanlar-kadifekalegazinosu-izmir/290030947825073/ Son Erişim Tarihi: 10.08.2020. Erişim Saati: 23:10

URL-3: https://twitter.com/nostalji_izmir/status/839193489506197505 Son Erişim Tarihi: 10.08.2020. Erişim Saati: 22:30

URL-4: https://www.gazetemizmir.com/iste-turkiye-nin-en-tehlikeli-mahalleleri/31752/ Son Erişim Tarihi: 02.11.2020. Erişim Saati: 15:30

URL-5: https://www.youtube.com/watch?reload=9\&v=4eLCbqreMFo Son Erişim Tarihi: 03.11.2020. Erişim Saati: 22:30

URL-6: https://www.youtube.com/watch?v=3NbRIcNvM6s Son Erişim Tarihi: 03.11.2020. Erişim Saati: 23:30

URL-7: https://eksisozluk.com/kadifekale--106703 Son Erişim Tarihi: 02.11.2020. Erişim Saati: 19:30 